\title{
QSAR of anti-inflammatory drugs
}

\author{
Veronica R Khayrullina ${ }^{*}, \mathrm{H}_{\text {Bögel }}^{2}$ \\ From 5th German Conference on Cheminformatics: 23. CIC-Workshop \\ Goslar, Germany. 8-10 November 2009
}

The computer analysis of relations between molecular structures and their biological activity using fragmentbased methods is very useful to draw conclusions for the understanding of drug action and for the development of more efficient non-toxic drug candidates.

We used the computer system SARD-21 (Structure Activity Relationship \& Design) to investigate common structural features (fragments and substituents) typical for high- and low-effective non-steroid anti-inflammatory drugs (NSAIDs) succesfully.

This derived information has been used for the model for prediction of anti-inflammatory effectiveness of medicines with $76 \%$ and $81 \%$ level of recognition by two methods. This information could be used for creating new highly effective NSAIDs, and for increasing effectiveness of already known components.

In a second part of this paper the interrelation between structure and efficacy for anti-inflammatory drug action is carried out using traditional QSAR with descriptors from topology and from quantum-mechanical calculations followed by regression models from modelling.

The aim of this paper is to compare both molecular approaches of molecular design of drugs.

\section{Author details}

${ }^{1}$ Bashkir State University, RU-450074 Ufa, Russia. ${ }^{2}$ Halle, Germany.

Published: 4 May 2010

\section{Reference}

1. Khayrullina VR, et al: Russ Chem Bull, Int Ed 2006, 55:1.

doi:10.1186/1758-2946-2-S1-P45

Cite this article as: Khayrullina and Bögel: QSAR of anti-inflammatory drugs. Journal of Cheminformatics 2010 2(Suppl 1):P45.

Publish with ChemistryCentral and every scientist can read your work free of charge

"Open access provides opportunities to our colleagues in other parts of the globe, by allowing anyone to view the content free of charge." W. Jeffery Hurst, The Hershey Company.

- available free of charge to the entire scientific community - peer reviewed and published immediately upon acceptance

- cited in PubMed and archived on PubMed Central

- yours - you keep the copyright

Submit your manuscript here:

http://www.chemistrycentral.com/manuscript/

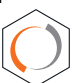
Chemistry Central 